Mutlu, H. H. ve Set, G. (2021). Kişiler bakımından çeviri çocuk romanları ile yerli çocuk romanlarının karşılaştırılması. Ana Dili Eğitimi Dergisi, 9(4), 1469-1487.

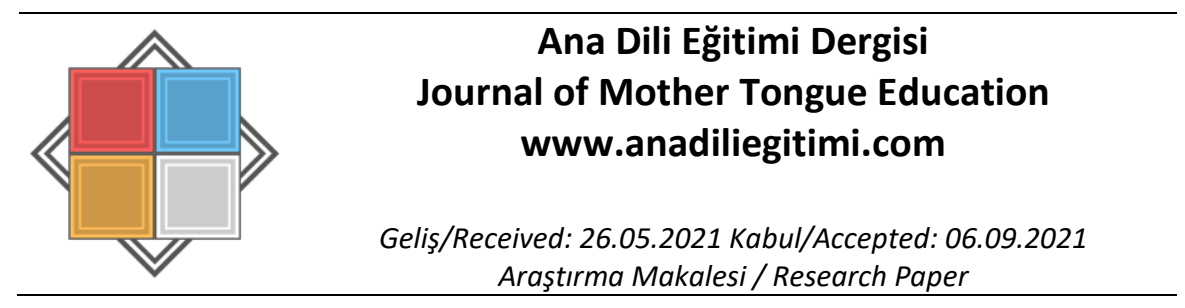

\title{
Kişiler Bakımından Çeviri Çocuk Romanları ile Yerli Çocuk Romanlarının Karşılaştırılması*
}

\author{
Hasan Hüseyin MUTLU** \\ Gülşah $S E T^{* * *}$
}

\begin{abstract}
Öz
Bu çalışmada çeviri çocuk romanları ile yerli çocuk romanlarındaki karakterler, nitelikleri, türleri, oluşturulma yöntemleri ve karakter eğitiminde kullanılıp kullanılamaması bakımından incelenmiştir. Çalışmanın evrenini en çok baskı yapan çeviri ve yerli çocuk romanları oluşturmaktadır. Örneklemini ise José Mauro De Vasconcelos'un Şeker Portakalı adlı çeviri çocuk romanı ve Zülfü Livaneli'nin Son Ada'nın Çocukları adlı yerli çocuk romanı oluşturmaktadır. Çalışmanın kuramsal çerçevesi oluşturulurken çocuk edebiyatı, çocuk edebiyatı yapıtlarının özellikleri, karakter kavramı ve karakter eğitimi başlıkları hakkında literatür taranmış, elde edilen bilgiler ve ilgili değerlendirmeler sunulmuştur. Çalışma, nitel araştırma türlerinden temel nitel araştırma deseni ile yapıımıștır. Doküman analizi yöntemi kullanılarak veriler toplanmış; incelenen romanlardaki karakterlerin nitelikleri, türleri, oluşturulma yöntemleri ve karakter eğitimi açısından değerleri belirlenmiş, tablolar halinde gösterilmiştir. Karakterler genel olarak benzer özelliklerde oluşturulmuş; hayvanseverlik, meraklıık, akıllı olma, duygusallık gibi özelliklerin çeviri ve yerli çocuk romanlarının kahramanlarının genelinde ortak özellikler olduğu görülmüş ve karakterlerin çoğunun, karakter eğitiminde kullanılabilecek yapıda oluşturulduğu sonucuna ulaşılmıştır.
\end{abstract}

Anahtar Kelimeler: Çocuk edebiyatı, çeviri edebiyat, çocuk romanı, karakter, karakter eğitimi

\section{Personal Comparison of Translated Children's Novels and Local Children's Novels Abstract}

In this study, the characters in translated children's novels and local children's novels were examined in terms of their qualities, types, creation methods, and whether they can be used in character education. The universe of the study consists of most printed translated children's novels and local children's novels. The sample is composed of the translated children's novel named José Mauro De Vasconcelos's Şeker Portakalı and the native children's novel named Zülfü Livaneli's Son Ada'nın Çocukları. While creating the theoretical framework of the study, the literature about children's literature, features of children's literature works, character concept and character education titles scanned, and the information obtained and related evaluations were presented. The study was carried out using a basic qualitative research design, which is one of the qualitative research types. Using document analysis method data were analyzed; qualities, types, creation of characters in novels examined methods and character education values are determined and shown in tables. Characters in translated children's novels and local children's novels were generally created with similar characteristics; it was discovered that animal-loving, curiosity, smartness, emotionality were common features in the heroes, and it was concluded that the majority of the characters were created in a structure that can be used in character education.

Keywords: Children's literature, translation literature, children's novel, character, character education

\footnotetext{
${ }^{*}$ Bu makale, birinci yazar danışmanlığında ikinci yazar tarafından hazırlanan aynı başlıklı tezden üretilmiştir.

${ }^{* *}$ Doç. Dr., Ordu Üniversitesi, Eğitim Fakültesi, Türkçe ve Sosyal Bilimler Eğitimi Bölümü, Ordu,

hasanhuseyinmutlu@hotmail.com, ORCID: orcid.org/0000-0002-9082-709X

*** Öğretmen, Ordu, setgulsah@gmail.com, ORCID: orcid.org/0000-0002-2503-6451
} 


\section{Giriş}

Çocuk edebiyatı çocuğun gelişim döneminde bilişsel gelişim seviyesi de dikkate alınarak duygu ve düşünceleri doğrultusunda oluşturulan edebiyattır (Şimşek 2018, s. 40). Sever'e (2008, s. 17) göre ise erken çocukluk çağı ile birlikte ergenlik dönemini de içine alarak çocukların bilişsel gelişim seviyelerine uygun bir şekilde duygu ve düşünce dünyalarını estetik bir değeri olan eserlerle zenginleştiren edebiyata çocuk edebiyatı denilmektedir. Çocuk edebiyatının temelinde çocuk olduğu için eserlerin dil, konu ve anlatım yönünden çocukların anlama, kavrama ve ilgi seviyelerine uygunluk göstermesi gerektiği anlaşılmaktadır (Sarıyüce, 2012, s. 9).

Çocuk edebiyatı ürünlerinin çocukları bilişsel, zihinsel ve duyuşsal yönden etkilemesinin yanı sıra en önemli katkılarından biri de çocukların dil gelişimini desteklemesidir. Çünkü çocuk edebiyatı ürünlerinin en önemli türlerinden biri olan kitaplar çocuğun dil seviyesine göre yazıldığı için onlara hitap edecek şekilde oluşturulmaktadır. Çocuklar okudukları kitaplardaki karakterler gibi davranıp, onlar gibi konuştuğu için çocuk kitaplarıyla ulaşılmak istenen kazanımlara bu noktalara dikkat edilerek daha kolay ve etkili şekilde ulaşılabilir (Akın 2019, s. 106-107). Çocuk edebiyatı ürünlerinin olumlu katkılarının yanı sıra olumsuz etkileri de görülebilir. Zira çocuklar bu edebiyat çıktıları ile kendi hayal dünyalarını oluşturur, analiz becerilerini geliştirir, bilgi edinir. Bunun yanında kitaplardaki kahramanlarla kendini özdeşleştirip onlar gibi de davranmaya çalışabilir. Dolayısıyla olumsuz iletiler, karakterler ve örnekler barındıran kitaplar çocukların karakter gelişimlerine olumsuz yönde etki edebilir.

Çocuk kavramını temel alarak oluşturulan çocuk edebiyatı eserlerinin çocukların bilişsel, zihinsel, duyuşsal ve dilsel gelişimlerini desteklemenin yanı sıra onlara okuma alışkanlığı kazandırmayı da amaçladığı söylenebilir. Gönen'e (2019, s. 287) göre de çocuklara okuma alışkanlığı kazandırabilmek için onları çocuklara yönelik hazırlanan kitaplarla erkenden tanıştırıp deneyimlemelerini sağlamak, gelecekte iyi birer okur olabilmeleri için önem arz etmektedir.

Çocuklarda tüm bu etkiler okudukları çocuk kitaplarındaki karakterler aracılığıyla gelişme gösterebilir. Çünkü çocuklar okudukları kitaplardaki karakterlerle özdeşim kurup, onlar gibi davranıp, onlar gibi konuşmak isteyebilir. Bu nedenle bu kitaplardaki karakterler oluşturulurken daha titiz davranılması ve çocuğa görelik ilkesine uygun bir şekilde oluşturulması gerektiği söylenebilir. Sever (2008, s. 76-77) bu durumla ilgili olarak çocukların okudukları kitaplarda karakterlerle özdeşim kurduğunu ve hayalî arkadaşlar edinerek güven duygularını geliştirdiklerini ifade etmektedir.

Çocukların kitaplardaki karakterlerle özdeşim kurabilmesi ile karakterlerin inandırıcılığını ve güvenilirliğini artırmak için bu karakterlerin günlük hayatta karşılaşılabilecek kadar gerçekçi ve çocuk okurun yaş seviyesinde olması gerekmektedir (Şimşek 2018, s. 101). Böylece karakterlerin yaşama azmi, problem çözme yetenekleri ve hedeflenen amaca ulaşmadaki çabalarının gerçekçi söz ve davranışlarla somutlanmasıyla çocuklar da onlar gibi davranmaya ve düşünmeye hevesli olur (Sever 2008, s. 77).

Çocuk edebiyatı eserlerindeki karakterlerin, çocukların kitap okuma alışkanlığı kazanmasında, dil gelişimi sürecinde, bilişsel gelişimlerine destek olmada, karakter gelişimine yardımcı olmada ve kitapların dikkat çekici birer unsur hâline gelmesinde önemli bir yerinin olduğu görülmektedir. Dolayısıyla oluşturulan karakterlerin özelliklerinin, türlerinin ve oluşturulma biçimlerinin incelenmesinin gerekli olduğu düşünülmektedir. Bu düşünceden hareketle en fazla baskı yapan yerli ve çeviri çocuk romanlarındaki karakterler birtakım ölçütlere göre analiz edilmiş ve karakter eğitiminde kullanııı kullanılamayacağına yönelik çıkarımlarda bulunulmuştur.

\section{Çocuk Edebiyatı Eserlerinde Kahraman/Kişi}

Edebi eserleri oluşturan önemli unsurlardan biri de kahramanlardır. Türkçe sözlükte kahraman kavramı: "Roman, hikâye, tiyatro vb. edebiyat türlerinde en önemli kişi" (TDK 2011, s. 1268) olarak tanımlanmıştır. Kahramanlar her türlü canlı veya varlıktan oluşabilir. Edebi eserlerde kahramanlar birçok işlev üstlenirler ve olaylardaki durumlarına ve görevlerine göre "baş kişi" ve "yan kişi" olarak isimlendirilirler. Baş kişi yani kahraman, eserlerde olayların temelinde olan ve olayları yaşayan, yönlendiren kişidir. Yan kişi ise dolaylı olarak olayların içerisinde yer alan kahramanlardır (Sever 2008, s. 76). 
Kahramanlar kişilik özellikleri ile birçok karaktere hayat verirler. Onları ön plana çıkaran, çocukların kendileriyle özdeşim kurdukları asıl şey kahramanların karakterleridir. Bu nedenle karakterlerin sahip olması gereken belirli özellikler bulunmaktadır. Karatay’a (2011, s. 100) göre karakterler; evrensel ve ahlakî değerlere sahip olmalı, her zaman iyiliğin ve doğrunun mücadelesini vermeli, barıştan yana olmalı, çevreye ve kültürel değerlere sahip çıkmalı ve olumlu kişilik özellikleri taşımalıdır.

Sever (2008, s. 104-105), karakterleri türlerine göre açık, kapalı, durağan ve devingen karakterler olarak sınıflandırmıştır:

\section{Açık (Geliştirilmiş) Karakter}

Roman, hikâye ve masal gibi edebi türlerde tüm özellikleri detaylı bir şekilde okuyucuya tanıtılan, inandırıcı özelliklere sahip olan ve okuyucunun da iyi tanıdığı karakterlerdir (Sever 2008, s. 104). Açık karakterler, kurgulanmış olayların içerisinde birçok farklı özelliğiyle okuyucunun hafızasına kazınır. Geliştirilmiş karakterlerin sahip olduğu belli başlı özellikler açık bir şekilde bilindiği halde bu bilgiler karakteri tam anlamıyla tanımaya yeterli olmayabilir. Karakterin iç dünyasına da hakim olmak gerekmektedir (Lukens, 1999; Sever, 2008'den akt., s. 104).

Çocukların kitaplardaki karakterlerle özdeşim kurabilmesi karakterlerin özelliklerine hakim olunmasına bağlıdır. Açık karakterler, okuyucu tarafından iyi bir şekilde tanındıkları için kitapta verilmesi amaçlanan ileti ve değerlerin kazandırılmasında çok önemli bir yere sahiptir (Sarıkaya, 2018, s. 17).

\section{Kapalı (Geliştirilmemiş) Karakter}

Kitaplarda üstünkörü bir şekilde tanıtılan, okuyucunun hakim olamadığı, hakkında pek fazla bilgi verilmeyen karakterlerdir. Olaylarda baş kişinin özelliklerinin daha iyi anlaşımasını ve çocukların bu kişiyle daha rahat özdeşleşmesini sağlamak için kapalı karakterlerden faydalanılmaktadır. Okuyucunun ilgisini kahramana çekmek için arka planda yer almaktadırlar. Bu karakterler yazınlarda kolay ve bilindik roller üstlenirler (Sever, 2008, s. 104-105). Kapalı karakter kavramını Uç (2006, s. 69) ise "Düz karakter, tek yönlü, basit kalmış, anonim davranış kriterlerine sahip karakter demektir." şeklinde açıklamıştır. Bu açıklamalardan yola çıkılarak kapalı karakterdeki roman kişilerinin birden fazla özelliğe sahip olmadıkları, belirli bir fikre sahip, pek değişiklik göstermedikleri sonucuna ulaşılabilir.

\section{Devingen (Dinamik) Karakterler}

Olayların başlangıcı ve sonucu arasında değişiklik gösteren karakterlerdir. Yeni davranışlar ve değerler oluşturulur. Karakterler bireysel mutlak doğrularından vazgeçip demokratik anlayışlar oluşturmak, bencilliği bırakıp paylaşımcı olmak gibi birçok değişim yaşayabilir. Ancak bu değişimlerin gerçekleşmesine sebep olan olaylar inandırıcı olmalı ve okuyucuda güven duygusu oluşturmalıdır. Olaylar ve karakterler arasında bir neden sonuç ilişkisinin olması çocuğun edebiyata olan ilgisinin devamı için önem arz etmektedir. Kahramanın geçirdiği değişimler idealize edilmiş özellikler bağlamında değil, insanın zayıfıkları üzerine kurgulanan durumlarla oluşturulursa, karakter çocuk okurun ilgisini çekebilir (Sever, 2008, s. 114-115). Bu nedenle karakterlerin yaşadığı değişikliklerin inandırıcı nitelikte olması gerekmektedir. Karakterler tüm özellikleriyle bir bütünlük taşımaktadır. illk başlarda olumlu, erdemli karakter özelliklerine sahip olan bir kişi kitabın ilerleyen bölümlerinde bu özelliklerinin tam tersi özellikler göstermeye başlarsa karakter inandırıcılığını kaybeder (Özdemir, 1995, s. 111). Sonuç olarak çocuk okurun kitaba olan ilgisini canlı tutan devingen karakterlerin inandırıcı özelliklerini kaybetmeden çocuk edebiyatı ürünlerinde daha fazla kullanılması gerekli görülmektedir.

\section{Durağan (Statik) Karakterler}

Kitap boyunca büyük değişimler yaşamayan, günlük hayatta karşılaşılabilecek karakterlerdir. Olaylar ne kadar uzun da sürse bu karakterlerin kişilik özelliklerinde pek değişiklik yaşanmaz. Kitabın başında olumlu veya olumsuz herhangi bir özelliğiyle anlatılan kahraman kitabın sonunda da benzer özellikler gösterir (Sever, 2008, s. 116). Uç (2006, s. 66) durağan karakteri kurgulanan metin boyunca gelişip değişmeyen kişilerin sahip oldukları nitelik olarak tanımlamıştır. Durağan karakterler çocuk 
edebiyatı ürünlerinde çocukların ilgisini pek çekmediği için tercih edilmese de oluşturulan kurgunun gerçekliğine katkı sağlaması için oluşturulabilir.

\section{Karakterlerin Geliştirilmesi}

Edebi eserlerde çeşitli karakter geliştirme biçimleri ve bu aşamada nelere dikkat edilmesi gerektiğiyle ilgili birçok araştırma yapılmıştır. Lukens'e (1999) göre karakterler "davranışlarıyla ve eylemleriyle, konuşmalarıyla, fiziksel özellikleriyle (dış görünüşüyle), diğer karakterlerin yorumlarıyla, yazarın yorumuyla" geliştirilebilir (Lukens, 1999).

Özdemir'e (1995, s. 110) göre ise karakterleri geliştirme yollarından bazıları doğrudan nitelikte olur. Yani dış görünüş ve kılık kıyafetlerini tasvir etme, içsel hayatlarını gösterme şeklinde olur. Bazıları ise dolaylı yolla geliştirilir. Yani davranışlarına yansıtarak ve konuşturarak yapılır. Kısacası karakterler anlatarak veya göstererek oluşturulur. Ancak bunlar tek başlarına yeterli olmaz, beraber kullanılmaları gerekir.

Karakter oluşturulurken kullanılan yöntemlerden biri, tanıtılmak istenen kişiyle ilgili bilgilerin doğrudan yazar tarafından açıklanması yani "açıklama yöntemi", diğeri ise karakterlerin davranışlarıyla, duygu ve düşünceleriyle kendi özelliklerini göstermeleri kısacası "dramatik yöntem"dir. Bu yöntemler ayrı ayrı kullanılabildiği gibi beraber de kullanılabilir. Dramatik yöntemde karakterlerin özellikleri bir anda verilmez, kitabın genelinde karakterlerin yaşayışlarından, duygu ve düşünce biçimlerinden, çevresine karşı tavırlarından anlaşııı. Açıklama yönteminde ise bu özellikler bir anda verilir, karakterin yaşantısına yerleştirilmez. Ancak okuyucular bazen dramatik yöntemle oluşturulmuş bazı karakterleri tam anlamıyla anlayıp tanıyamayabilir. Böyle bir durumda ise açıklama yönteminden faydalanılabilir (Tekin, 2004, s. 80-81). Verilen bilgilerden anlaşılacağı üzere karakter geliştirilirken açıklama yöntemi ile dramatik yöntemi beraber kullanmak okuyucunun karakterleri tam anlamıyla algılayabilmesi için daha faydalı olabilir.

Yapılan araştırmalardan yola çıkılarak çocuk kitaplarındaki kahramanların çocuk gerçekliğine uygun, tutarlı, inandırıcılığı olan, çocukların özdeşim kurmak isteyecekleri şekilde oluşturulmalarının önemli olduğu söylenebilir. Kahramanların her türlü ortamdan olabilmesi ve çok fazla ana kahramana sahip olmaması kitapların inandırıcılığı ve çocuğun kitaba olan ilgisi açısından önemli görülebilir. Kitaplardaki kahramanların özelliklerinin çocuklara uygun ve doğru bir şekilde oluşturulmasının çocuklara birçok açıdan katkı sağlayacağı düşünülmektedir.

\section{Karakter Ĕgitimi}

Karakter eğitimi Aristo, Kant ve Sokrates döneminde görülmeye başlanmıştır. Ayrıca tüm kutsal kitaplarda ahlaktan ve iyi karakterden bahsedilmektedir. Din kaynaklı olsa bile tüm toplumlarda karakter eğitimi verilmektedir. Karakter eğitiminin programlı bir şekilde okullarda verilmeye başlanması 1990'lara rastlamaktadır. Bu durum okulların ahlaki açıdan gelişim sağlaması ile belirmiştir (Çağatay, 2009, s. 28).

1900'lerin başlarında ahlak eğitimi, ahlaki konuları inceleyip bunları davranış olarak kazandırmakla uğraşmıştır. Ahlak eğitimi bu dönemde sadece okulun değil toplumun da bir sorumluluğu olarak görülmüştür. Kutsal kitaplar da ahlaki davranış kılavuzu olarak kullanılmıştır. Ancak 1920 ve 1930 'lara gelindiğinde karakter eğitimi ile ilgili olumsuz düşünceler yayılmaya başlanmıştır. Bu da resmi olarak yapılan karakter eğitimlerinde düşüşe neden olmuştur (Aslan, 2011, s. 22).

1950 'li yıllarda ise artan genç intiharlar, cinayetler ve risli gebelikler nedeniyle bu sorunları çözmek için okullarda karakter eğitimi tekrar düzenlenmiştir (Wynne, 1985, s. 8). 1960'lara gelindiğinde ise toplumun özerklik ve bireysel hakları ile ilgili fikirlerden dolayı karakter eğitimi tekrar düşme yaşamıştır (Lickona, 1993, s. 7).

1980 ve 1990 'lar süresince değerlerin ortaya çıkarılmasını ahlaki açıdan göreceli ve karakter gelişimi yönünden zararlı olarak değerlendiren Amerikalı eğitimciler tekrar karakter eğitimine dönülmesi gerektiğini savunmuşlardır (Milson vd., 2003, s. 100). Karakter eğitiminin tekrar gündeme gelmesi gençlerdeki davranış bozukluklarına, aile birliğinin bozulmasına ve çocukları korumaya yönelik olan ahlaki birliğin oluşmasına bağlıdır (Lickona, 1993, s. 10). 
Karakter eğitimi en eski eğitimdir. Amacı her zaman insanlara yardım etmek olmuştur. Ahlaki sorunların çoğalmasıyla karakter eğitiminin önemi anlaşılmış ve tekrar bu alana odaklanılmaya başlanmıştır. Gençlerin ahlaki açıdan yönlendirilmesi gerektiği anlaşıımıştır. Bu durumda aile ve öğretmenlere ahlak eğitiminin sürekliliği için bazı sorumluluklar düşmektedir. Okul, iyi değerleri yerleştirmede ve karakter eğitimini bu değerlerle birleştirme konusunda önemli bir yere sahiptir (http://www.cortland.edu/character/articles/history2.html). Ancak okullarda uygulanan her ahlak eğitiminin karakter eğitimi olduğu söylenemez. Verilen eğitimin karakter eğitimi olabilmesi için amacının karakterleri şekillendirmek olması gerekmektedir. Böyle bir amaç varsa öğrencinin karakterini geliştirmek için yapılan girişimler karakter eğitimi olarak nitelendirilebilir (Davis, 2003, s. 34-35).

Çocuk kitaplarındaki karakterler çocukları eğlendirip estetik açıdan tatmin etmenin yanı sıra bazı değerleri ve kazanımları iletmek, onların karakter oluşumlarına destek olmak açısında önemli bir yere sahiptir. Bu nedenle çocuk kitaplarındaki karakterlerin çocukların özdeşim kurabileceği nitelikte olması gerektiği için olumlu özellikler göstermesi beklenmektedir. Yapılan araştırmalara göre karakter eğitimiyle ulaşılmak istenen bireysel ve toplumsal bazı hedefler bulunmaktadır. Karatay'a (2011, s. 1402) göre: "Karakter eğitiminin amacı öğrencilerin iyiyi tanımaları, istemeleri ve nihayetinde iyi eylemlerde bulunmalarına yardımcı olmaktır." Noddings'e (2006) göre ise erdemli bireyler yetiştirebilmek için gösterilen çabaya karakter eğitimi denilmektedir.

Türk kültüründe de iyi, karakterli insan yetiştirmenin önemi ile ilgili birçok kaynaktan söz edilmektedir. Dönmez ve Koçak'ın (2018) Kutadgu Bilig ile ilgili yaptıkları çalışmada Yusuf Has Hacip'in mutluluğun ancak çocukların eğitilmesi ile mümkün olduğunu, mutluluk için dürüst, akıllı, merhametli, iyi kalpli, hayâ sahibi ve alçakgönüllü olunması gerektiğini vurguladığı belirtilmiştir.

Karakter eğitiminde toplum kaynaklı faktörler etkili olsa bile aslında okul temelli bir programdır ve bu durumda öğretmenler önemli görevler üstlenmektedir. Kurgusal metinlerden yararlanarak çocuklara olumlu karakter özellikleri kazandırmak da bu görevlerden biridir (Yılmaz, 2016, s. 313). Çocukların ilgi ve ihtiyaçları, seviyeleri hesaba katılarak basılan kitaplar çocukların karakter gelişiminde oldukça önemli bir yere sahiptir. Kazandırılmak istenen davranışlar kitapların içeriğine çocukların okurken sezebilecekleri şekilde yerleştirilir. Bunun için çocukların iyi oluşturulmuş çocuk kitaplarına gereksinimi vardır (Çılgın, 2007, s. 15).

Çocuk kitaplarındaki gerçekliğe uygun ve çocukların girişimciliğine katkı sağlayacak davranışlar, çocuklarda aynı davranışları yapmaya istek uyandırır (Sever, 2008, s. 57). Bu da çocuğun ilerde okuduğu kitaplardaki gibi bir karakter geliştirmelerine yardımcı olabilir. Sonuç olarak çocuklara karakter eğitimi en iyi onlar için oluşturulmuş nitelikli çocuk kitapları ile verilebilir. Kitaplardaki iyi oluşturulmuş, çocukların kişiliklerine olumlu etkiler bırakacak karakterler onların düşünen, sorgulayan, empatik bireyler olarak yetişmelerine yardımcı olabilir. Bu da hem çocuğun hem de dolaylı olarak toplumun refahı için önemli görülmektedir.

Çocuk edebiyatı eserlerindeki karakterlerin, çocukların kitap okuma alışkanlığı kazanmasında, dil gelişimi sürecinde, bilişsel gelişimlerine destek olmada, karakter gelişimine yardımcı olmada ve kitapların dikkat çekici birer unsur hâline gelmesinde önemli bir yerinin olduğu görülmektedir. Dolayısıyla oluşturulan karakterlerin özelliklerinin, türlerinin ve oluşturulma biçimlerinin incelenmesinin gerekli olduğu düşünülmektedir. Bu düşünceden hareketle en fazla baskı yapan yerli ve çeviri çocuk romanlarındaki karakterlerin birtakım ölçütlere göre analiz edilmesi ve karakter eğitiminde kullanılıp kullanılamayacağına yönelik çıkarımlarda bulunulması amacıyla bu çalışma gerçekleştirilmiştir.

\section{Araştırmanın Modeli}

\section{Yöntem}

Bu çalışma, nitel araştırma türlerinden olan temel nitel araştırma deseni ile gerçekleştirilmiştir. Temel nitel araştırma deseni tüm disiplinlerde, pratik uygulama alanlarında görülebilen ve en sık kullanılan nitel araştırma desenlerinden biridir. Bu tür araştırmalarda veriler görüşme, gözlem veya doküman analizi yoluyla oluşturulur (Merriam, 2013). Bu araştırma modeliyle literatür taranmış ve karakterlerin nitelikleri, nasıl geliştirildikleri, özellikleri ve karakter eğitiminde kullanılabilme durumları belirlenmeye çalışılmıştır. 


\section{Örneklem / Araştırma grubu}

Araştırmanın evreni en fazla baskı yapan yerli ve çeviri çocuk romanlarından oluşmaktadır. Örneklemi ise en fazla baskı yapan bir yerli ve bir çeviri çocuk romanından oluşmaktadır. Örneklem amaçlı örnekleme yöntemiyle belirlenmiştir.

Araştırmada incelenen yerli ve çeviri çocuk romanları şunlardır:

- Son Ada'nın Çocukları

- Şeker Portakalı

Tablo 1.

Yerli ve Çeviri Çocuk Romanları Künyeleri

\begin{tabular}{|c|c|c|c|c|c|}
\hline Kitap Adı & Kitabın Yazarı & Yayınevi & Yayın Yılı & Yayın Yeri & Baskı Sayısı \\
\hline $\begin{array}{l}\text { Son Ada'nın } \\
\text { Çocukları }\end{array}$ & Zülfü Livaneli & $\begin{array}{l}\text { Doğan } \\
\text { Egmont }\end{array}$ & 2019 & İstanbul & 83 \\
\hline $\begin{array}{l}\text { Şeker } \\
\text { Portakalı }\end{array}$ & $\begin{array}{l}\text { JoséMauro De } \\
\text { Vasconcelos }\end{array}$ & Can Yayınları & 2018 & İstanbul & 132 \\
\hline
\end{tabular}

\section{Veri Toplama Araçları}

Araştırmanın veri toplama araçlarını alanda kabul görmüş ve birçok çalışmada (Sarıkaya, 2018; Karataş, 2014; Baş ve Ucuzsatar, 2020) kullanılmış olan Sever'in (2008) Çocuk ve Edebiyat adlı kitabında belirttiği kıstaslar (açıklık veya kapalıık, devingenlik veya durağanlık) ve Tekin'in (2004) Roman Sanatı adlı kitabında belirttiği karakter geliştirilme biçimleri ve karakter eğitimine uygun olup olmaması ölçütleri oluşturmaktadır.

\section{İşlem / Verilerin Toplanması}

Araştırmada veriler doküman analizi yoluyla toplanmıştır. Doküman analizi daha önceden var olan belge ve kayıtların incelenerek verilerin toplanması işlemine denilmektedir ve belli bir amaç doğrultusunda kaynaklar bulma, bunları okuma, not alma ve değerlendirme işlemlerini kapsar (Karasar, 2012, s. 183).

\section{Verilerin Analizi}

Çalışma sürecinde kullanılan çeviri ve yerli çocuk kitapları kişi kavramı dikkate alınarak okunmuştur. İçerik analizi yöntemi ile amaca uygun olarak karakter niteliklerini ve geliştirilme biçimlerini oluşturan kıstaslara göre bu kitaplardaki kişiler analiz edilmiştir.

\section{Geçerlik ve Güvenirlik}

Araştırmanın geçerliğinin ve güvenirliğinin sağlanması için kapsamlı bir alanyazın taraması yapılmış; verilerin toplanması ve analizi aşamasında kullanılan ölçütler alanında uzman akademisyenlerden uzman görüşü alınarak listelenmiş ve dönütler çerçevesinde düzenlenip çalışmaya uygulanmıştır.

\section{Araştırma ve Yayın Etiği}

Bu çalışmada "Yükseköğretim Kurumları Bilimsel Araştırma ve Yayın Etiği Yönergesi" kapsamında uyulması belirtilen tüm kurallara uyulmuştur. Yönergenin ikinci bölümü olan "Bilimsel Araştırma ve Yayın Etiğine Aykırı Eylemler" başlığı altında belirtilen eylemlerden hiçbiri gerçekleştirilmemiştir.

\section{Etik Kurul izni}

Çalışmada kitaplar incelendiği için etik kurul iznine ihtiyaç duyulmamaktadır. 


\section{Bulgular}

Çalışmanın bu kısmında örneklem olarak seçilen yerli ve çeviri çocuk romanlarında incelenen karakterlerle ilgili bulgu ve yorumlara yer verilmiştir.

\section{Son Ada'nın Çocukları Karakter incelemeleri Yazar}

Doğasever-Hayvansever: Kitabın başkahramanı olan yazar, babasının ölümünden sonra annesi ve dayısı ile beraber yaşamaya başladığı adayı, adadaki bitkileri, hayvanları çok sevmektedir. Öyle ki okula gitme zorunluluğu olmasa sürekli bu adada yaşamak ister:

"Adamızı anlatmaya nereden başlasam bilemiyorum. Şimdi size bu küçük adanın yemyeşil çam ormanlarından, doğal bir akvaryum gibi olan masmavi denizinden, rengârenk balıkların seyredildiği güzel koylarından, sürekli uçan bembeyaz martılarından söz etsem, eminim ki gözünüzde ancak basit bir manzara resmi canlandırabileceğim. Oysaki adamızın eşi benzeri yoktu, sanki büyülü bir yerdi." (Livaneli, 2019, s. 11)

Alçakgönüllü: Yazar, adayla ilgili bilgi verirken kendisinin daha yeni bir yazar olduğunu, bu yüzden de anlatırken kelimelerinin yetersiz kalacağını söyleyerek alçakgönüllü bir karaktere sahip olduğunu göstermektedir:

"Ben henüz çok genç bir yazar olduğum için bunları anlatmaya kelimelerim yetmiyor. Aslına bakarsanız bu hikâyeyi size yazar dayım anlatmalıydı ama o benim yazmamı istedi. Dayım bütün bunları kim bilir ne kadar zengin ve sürükleyici bir dille iletirdi size." (Livaneli, 2019, s. 12)

Iyimser: Her şeye olumlu tarafından bakan yazar, dayısına bazı konularda çok karamsar olduğunu, olaylara olumlu tarafından bakmak gerektiğini söyler. Her şeyin mantıkı bir açıklaması olduğunu düşünmektedir. Bu da yazarın iyimser bir karakter özelliği taşıdığını göstermektedir:

"Yine de tıpkı babam gibi, ülkemizdeki insanların tekrar dost olabileceğine dair umudumu yitirmemiştim. Kim bilir? Belki benim yaşımdakiler büyüyünce ülkemize tekrar barış gelir." (Livaneli, 2019, s. 39)

Merhametli: Başkan'ın torunu, adadaki çocukları küçümseyip onlarla alay etmesine rağmen martı saldırısına uğradığında yazarın onun hâline üzülmesi merhamet duygusu taşıdığını göstermektedir:

"Kıza gıcık olsam da bu olaya çok üzüldüm. Birkaç komşumuzla ada halkı adına, Başkan’a geçmiş olsun ziyaretine gitmeyi bile önerdim ama büyükler cesaret edemediler." (Livaneli, 2019, s. 49)

Merakı: Yazar onca olayın ardından oluşan sessizliğin arkasında neler olup bittiğini merak edip kendi kendine sorular sormaktadır:

"Hiçbirimiz ses çıkarmadık. Gece sessizdi, martı çığıkları duyulmuyordu, adada çıt çıkmıyordu. Acaba Başkan planında başarılı olmuş ve bütün martıları adadan kovmuş muydu? Niye o gün öğleden sonra ya da akşamüstü hiç uçan martı görmemiştik?" (Livaneli, 2019, s. 113)

Girişken: Yazar çevresinde olanlara seyirci kalmayan, adanın eskisi gibi olması için çabalayan, yeni fikirler ortaya atan, herkesle etkileşim içinde olan girişken bir yapı sergilemektedir:

"Süper bir fikrim var dayı. Yarın herkese haber verip fıstık toplama işine başlayalım. Yine her yılki şenliklerimizi yapalım. Fıstıkları çuvallara doldurunca toplu akşam yemeğimizi yiyelim; müzisyen abilerim gelsinler, dans edelim. Böyle neşeli bir ortamda Başkan da unutulur gider, onun martı savaşı da!" (Livaneli, 2019, s. 101-102)

Karakterle ilgili Genel Değerlendirme: Kitabın başkahramanı olan yazar oluşturulurken çevresiyle olan ilişkisi, davranışları, konuşmaları ve olaylara karşı tutumu temel alınmıştır. Yazarın karakter özellikleri açık ve net bir şekilde ortaya koyulmuştur. Karakter özellikleri birbiriyle tutarsız değildir. Bu özellikler kitapta sıkça tekrar edildiği için okuyucunun zihninde net bir şekilde yer etmektedir. Açık karakter özelliği gösteren yazar, kitap boyunca sürekli aynı özellikleri sergilemiştir. Pek değişiklik göstermediği için durağan bir yapıya sahiptir.

Yazarın açık karakter özelliği göstermesi olumlu bir durumdur. Yaşına göre olgun, her zaman umutlu, yeri geldiğinde büyüklere öncülük eden, hayvansever, doğasever olma özellikleri karakter eğitiminde kullanılabilecek niteliklerdir. Ancak karakterin sürekli olumlu özellikler göstermesi, yetişkin 
bir insan gibi davranması okuyucunun ilgisini canlı tutmakta yetersiz kalabilir. Yazar, çocuk dünyasına yakın bir profilde değildir. Bu da okuyucunun karakterle özdeşim kurmasını zorlaştırabilir. Yazarın sahip olduğu tüm nitelikler karakter eğitiminde kullanılabilir. Buradan da karakterin idealize edildiği sonucuna ulaşıır.

\section{Başkan}

Kindar: Başkan, gece terasında duyduğu ayak seslerinin insana değil de bir martıya ait olduğunu ortaya çıkarıp kendisini gülünç duruma düşüren anlatıcının dayısına ve martılara kin gütmeye başlar ve adada yaşanacak korkunç olayların fitili bu olayla ateşlenir:

"Arkadaşlar, adanıza geldiğim günden sonra burada oturan ada halkının geçmişi hakkında bazı araştırmalar yaptırdım ve böylece sözde yazar olan arkadaşın müthiş sırrı ortaya çıktı. Bu kişi, devletimize karşı geldiği için hapse girmiş ve çıktıktan sonra adını değiştirerek adanıza sığınmış bir suçludur. Bu adam hepimizi kandırmıştır." (Livaneli, 2019, s. 180-181)

Acımasız: Başkan merhamet duygusunu yitirmiş, gözünü kırpmadan canice kararlar alabilen, duyarsız, bencil bir karakterdir. O gelene kadar adada kimsenin bir sorun yaşamadığı martıları, yaptığı türlü planlarla katletmiş; martıları yok etmek için getirttiği tilkileri yok etmek için de ormanları yakmıştır. Bunları yaparken de kimseyi dinlememiş, kafasına estiği gibi hareket etmiştir:

“Başkan alaycı bir edayla, 'Kaçırmaktan söz eden kim?' dedi. 'Yok edeceğiz."

"Nasıl?"

"Hepsini avlayacağız, yumurtaları da kıracağız. Anlayacağınız bir çeşit av şöleni." (Livaneli, 2019, s. 84)

Bencil: Başkan'ın hayatî durumlarda bile sadece kendisini düşünmesi, ada halkının canını hiçe sayması, yılan ısırmaları için gerekli ilacı bir dediğini iki etmeyen, onu el üstünde tutan adadaki diğer hastalara vermeyip kendisinin yılan tarafından ısırıldığında kullanması bencil bir karaktere sahip olduğunun göstergesidir:

"Günlerce ateşler içinde yatmasına, çok acı çekmesine rağmen hayati tehlikeyi atlatmıştı. Bu durum, özel teknesinde her ihtiyacı karşılayabilecek malzemeler bulundurduğunu ama elindeki ilaçları adalılar için kullanmadığını da ortaya çıkarmışıı." (Livaneli, 2019, s. 150)

Karakterle Illgili Genel Değerlendirme: Başkan'ın karakter özellikleri açık bir şekilde belirtilmiştir ve bu özellikler birbiriyle tutarsız değildir. Başkan, açık karakter özelliği göstermiş ve kitap boyunca sürekli aynı özellikleri sergilemiştir. Kitap boyunca karakter özellikleri pek değişiklik göstermediğinden durağan bir yapıya sahiptir.

Başkan'ın açık karakter özelliği göstermesi olumlu bir durumdur. Ancak sahip olduğu özellikler karakter eğitiminde kullanılabilecek nitelikler değildir. Kindar, bencil olması, hayvanlara eziyet etmesi, sadece kendi çıkarlarını gözetmesi ve insanları kullanması çocuk okur için olumsuz örnekler teşkil etmektedir. Buradan da karakterin idealize edilmediği sonucuna ulaşılır.

\section{Yazarın Dayısı}

Yazarın dayısına kitapta pek ayrıntılı yer verilmemiştir. Dayı, yeğenine ve adadaki diğer insanlara karşı güler yüzlü, sevecen bir şekilde davranmaktadır. Adaya karşı çok duyarlıdır. Başkan geldikten sonra karamsar ve ön yargılı bir havaya bürünmüş ve bu özellikleriyle ön plana çıkmıştır. Çünkü geçmiş tecrübelerine ve bilgilerine dayanarak adanın tehlike altında olduğunu hissetmiş ve herkesi uyarmaya çalışmıştır. Bu süreçte aldığı kararlar ve attığı adımlar akıllı ve cesur bir karaktere sahip olduğunu göstermektedir. Sonuç olarak dayı görevindeki kişi kapalı ve durağan karakter özelliği gösterse bile sahip olduğu olumlu karakter nitelikleri açısından okurun özdeşim kurmak isteyeceği bir karakter izlenimi oluşturmuştur. Kısacası karakter eğitiminde kullanılabilecek bir görüntü oluşturmuştur. 
Tablo 2.

Son Ada'nın Çocukları: Karakterlerin Genel Görünümü

\begin{tabular}{llll}
\hline Karakterler & Karakter Türü & $\begin{array}{l}\text { Karakterin Geliştirilme } \\
\text { Biçimi }\end{array}$ \\
\hline Yazar & Baş Kişi & Açık, Durağan & Dramatik \\
Başkan & Baş Kişi & Açık, Durağan & Dramatik, Açıklama \\
Yazarın Dayısı & Yan Kişi & Açık, Durağan & Dramatik, Açıklama \\
\hline
\end{tabular}

Tabloya bakıldığında romanda ele alınan karakterlerin hepsi durağan bir yapıya sahiptir. Başkişiler açık karakter özelliği gösterirken yan kişi kapalı karakter özelliği göstermektedir. Karakterlerin hepsinin dramatik yöntemle geliştirilmesi ele alınan karakter özelliklerinin daha gerçekçi bir şekilde verilmesine olanak sağlamıştır. Ayrıca Başkan ve Yazarın Dayısı karakterleri geliştirilirken dramatik yöntemle beraber açıklama yönteminin de kullanılması bu karakterler hakkında okuyucunun kafasında soru işaretleri oluşmasını önlemiştir.

Tablo 3.

Son Ada'nın Çocukları: Karakter Nitelikleri

Yazar Karakteri

Karakter Eğitiminde

Kullanılabilecek Nitelikler

Hayvansever,Alçakgönüllü,

Girişken, Doğasever, Meraklı, İyimser
Karakter Eğitiminde

Kullanılamayacak Nitelikler

Yazarın tüm özellikleri olumludur. Karakter eğitiminde kullanılması uygun bulunmayan hiçbir özellik taşımamaktadır. Karakter tamamen olumlu özelliklerle oluşturulduğu için idealize edilmiş bir karakter olduğu sonucu ortaya çıkmaktadır.

Tablo 4.

Son Ada'nın Çocukları: Karakter Nitelikleri

Başkan Karakteri

Karakter Eğitiminde Kullanılabilecek Nitelikler Karakter Eğitiminde Kullanılamayacak Nitelikler

$x$

Kindar, Bencil, Acımasız

Başkanın bütün özellikleri olumsuzdur ve bu özellikler karakter eğitiminde kullanmak için uygun bulunmamaktadır. Karakterin olumlu bir özelliği bulunmadığı için idealize edilmemiş bir karakter olduğu görülmektedir.

\section{Şeker Portakalı}

\section{Karakter Incelemeleri}

Zezé

Yaramaz: Kitabın başkahramanı olan Zezé, herkesin yaka silktiği, aklına her türlü hinlik gelen yaramaz bir çocuktur. Fazlaca yaramazlık yaptığı bir gün ablası tarafından dayısının yanına gönderilir 
ama orada da rahat durmaz. Önce dayısının gözlüğünü saklayıp bulmak için para ister sonra da sakladığı yerde çıkarırken dayısına yakalanır ve dayak yer:

“Bir gün çok azgınlık ettiğimde Glória beni Dindinha'nın evine yolladı. Dayım oradaydı, gazetesini okumak istiyor ama gözlüğünü bir türlü bulamıyordu. Aradı durdu, bulamadıkça öfkelendi. Dindinha'ya sordu, ama o da bulamadı. i̇kisi beraber evin altını üstüne getirdiler. Sonra ben gözlüğün yerini bildiğimi, misket almam için biraz bozukluk verirse gösterebileceğimi söyledim. Askıdaki yeleğinin cebinden birkaç bozukluk çıkardı. 'Gidip getirirsen vereceğim,' dedi. Kirli çamaşır sepetine gidip gözlüğünü çıkardım. Dayım bunu görünce küfrü bastı. 'Demek sen sakladın, vay hergele!' Kıçıma şaplağı indirdi ve verdiği bozukluğu geri aldı." (Vasconcelos, 2018, s. 17)

Meraklı: Yoksul bir ailede yaşayan Zezé evdeki herkes çalıştığı için vaktini genellikle ya dayısının yanında ya da sokaklarda geçirir. Etraftakilerden duyduğu bazı şeyleri gelip evdekilere sorar, iyice öğrenmek ister. Bu da meraklı bir karakter özelliğine sahip olduğunun göstergesidir:

"Ariovaldo Efendi, hani siz eskiden bana cingöz diyordunuz ya, o ne demek?"

"Yurdum, mübarek Bahia'da küçücük, minicik bacaksızlara denir..." (Vasconcelos, 2018, s. 88)

Zeki: Her ne kadar yaramaz da olsa Zezé çok zeki bir çocuktur. Yaptığı yaramazlıklar bile onun zeki olduğunun bir göstergesidir. Öyle ki okuma yazma bilmediği ve kimse de öğretmediği hâlde kendi kendine okumayı öğrenir. Ablasına okuyabildiğini söylediğinde ablası inanmaz ancak Zezé okuyup da bunu gösterince çok şaşırır:

"Beni kucağına alıp kapının hizasında kaldırmıştı.

'Oku bakalım. Görelim.'

Sahiden de okuyuvermiş̧im. Tanrı'nın evi kutsayıp kötü ruhları kovmasını dileyen duayı baştan sona okumuştum." (Vasconcelos, 2018, s. 21-22)

Duygusal: Her ne kadar yaramaz ve umursamaz da olsa Zezé aslında duygusal bir çocuktur. Kolayca üzülüp ağlayan, üzüldüğü durumların etkisinden hemen çıkamayan, sevdiği insanlarla derin bağlar kurup onları mutlu etmek için elinden geleni yapan bir karakter özelliğine sahiptir. Öyle ki annesinin işten geldikten sonraki yorgun hâlini görünce ona çok acır ve üzülür. Büyüyünce ona sürprizler yaparak mutlu edeceğine kendi kendine söz verir:

"Sesi bitkin mi bitkin çıkıyordu. Ona öyle acıyordum ki... Annem doğduğundan beri çalışıyormuş. Henüz altı yaşındayken fabrika kurulunca onu orada işe sokmuşlar. Annemi bir masanın tepesine oturtur, temizleyip cilalasın diye alet edevatı önüne yığarlarmış." (Vasconcelos, 2018, s. 3132)

Sinirli: Zezé, ani çıkışları olan, istediği bir şey olmadığında ya da işine gelmeyen durumlarda çok çabuk sinirlenip karşısındakine küfürler savuran bir karakter yapısına sahiptir. Öyle ki ailesinde en çok sevdiği kişi olan Glória'ya bile çok da önemli olmayan bir konu yüzünden sinirlenip küfreder:

"Şeytan seni!" diye bağırdım. "Rengi bozuk! Harp Okulu'ndan kimse senle evlenmeyecek! Postallarını boyatacak parası bile olmayan şu beş parasız erlerden biriyle evlenirsin anca!" (Vasconcelos, 2018, s. 39)

Hayalperest: Zezé, hayal dünyası çok geniş bir çocuktur. Kurduğu oyunlar hatta yaptığı yaramazlıklar bile kimsenin aklına gelmeyecek, geniş bir hayal gücü gerektirmektedir. Üzgün olduğu zamanlarda bile kurduğu hayal dünyası onu neşelendirmektedir. En yakın arkadaşının bir şeker portakalı ağacı olması da Zezé’nin hayal dünyasının bir ürünüdür.

"Luciano'nun hayvan olmadığına kardeşimi ikna edene kadar akla karayı seçmiştim. Luciano, Campodos Afonsos dolaylarında süzülen bir uçaktı." (Vasconcelos, 2018, s. 26-27)

Karakterle İlgili Genel Değerlendirme: Kitabın başkahramanlarından biri olan Zezé karakteri oluşturulurken çevresiyle olan ilişkisi, davranışları, konuşmaları ve olaylara karşı tutumu ele alınmıştır.

Zezé'nin karakter özellikleri açık ve net bir şekilde ortaya koyulmuştur. Karakter özellikleri birbiriyle tutarsız değildir. Bu özellikler ilgi çekici özelliklerdir. Çünkü çocuk gerçekliğine uygun olarak oluşturulmuştur. Açık karakter özelliği gösteren Zezé, kitap boyunca sürekli aynı özellikleri sergilememiştir. Olumlu özelliklerini bulunduğu gibi olumsuz özellikleri de bulunmaktadır. Kitabın başlarında olumsuz özellikleriyle öne çıkarken çok sevdiği arkadaşını kaybedince değişmiş ve sessiz, sakin, ağırbaşlı bir görüntü oluşturmuştur. Bu da devingen bir yapıya sahip olduğunu göstermektedir. 
Zezé'nin açık karakter özelliği göstermesi olumlu bir durumdur. Meraklı, duygusal, zeki ve hayalperest olması karakter eğitiminde kullanılabilecek niteliklerdir. Ancak yaramaz ve sinirli olması karakter eğitiminde kullanılamayacak özellikler de taşıdığını göstermektedir. Karakterin sadece olumlu özelliklerinin değil çocuklara özgü yaramazlıklarının, inatlaşmalarının da olması okuyucunun kitaba olan ilgisini canlı tutacaktır. Zezé karakteri, çocuk dünyasına yakın bir görüntü oluşturmaktadır. Bu da okuyucunun karakterle özdeşim kurmasını, kendisini olayların içinde hissetmesini kolaylaştırabilecek bir durumdur. Buradan da karakterin idealize edilmediği sonucuna ulaşılır.

\section{Manuel Valadares}

Şefkatli: Kitabın başkahramanlarından olan Manuel Valadares yalnız yaşamaktadır. Tek çocuğu olan kızı Portekiz'de yaşadığı için evladı gibi sevdiği Zezé’ye çok düşkündür. Bazen sert ve acımasız biri gibi bir görüntü çizse de aslında tam tersi çok şefkatli bir insandır.

"Seni çok seviyorum, bızdık. Sandığından çok daha fazla. Hadi, gülümse." (Vasconcelos, 2018, s. 146-147)

Kibar: Portekizli yani Manuel Valadares, görünenin aksine kibar ve düşünceli biridir. İnsanları kırmamaya özen gösterir. Yine Zezé’yle sohbet ettikleri bir gün Zezé'nin bir sorusuna kibar bir karaktere sahip olduğunu gösteren bir cevap verir:

"Hayır, çünkü ben kral değilim ve kimseye emir vermem. Senden bir şey isteyeceğim zaman mutlaka rica ederek isterim." (Vasconcelos, 2018, s. 151)

Karakterle ilgili Genel Değerlendirme: Manuel Valadares karakteri oluşturulurken çevresiyle olan ilişkisi, davranışları, konuşmaları ve olaylara karşı tutumu dikkate alınmıştır.

Portekizlinin karakter özellikleri açık ve net bir şekilde ortaya koyulmuştur. Karakter özellikleri birbiriyle tutarsız değildir. Bu özelliklerin ilgi çekici özellikler olduğu söylenemez. Ama bu özelliklerin veriliş şekli ve diğer karakterlerle harmanlanışı okuyucunun ilgisini çekebilir. Açık karakter özelliği gösteren Portekizli, kitap boyunca sürekli aynı özellikleri sergilemiştir. Olumlu özellikleri ön plana çıkarılmıştır. Karakterle ilgili olumsuz bir duruma yer verilmemiştir. Bu da karakterin durağan bir yapıya sahip olduğunu göstermektedir. Durağan bir karaktere sahip olsa da yazar bu durağanlı̆̆ın sebebini okuyucuya aktarabildiği için karakter sıkıcı olmaktan çıkmıştır. Ayrıca bu durağan karakter Zezé'nin devingen karakteriyle bütünleşince çocuk okurun ilgisini çekecek duruma gelmiştir.

\section{Şeker Portakalı}

Kitabın ana karakterlerinden biri olan Şeker Portakalı yani Minguinho, Zezé'nin en yakın arkadaşıdır. Zezé hayalinde Minguinho'yu konuşturur ve onunla oyunlar oynar. İçindekileri hep Minguinho'ya anlatır. Minguinho da Zezé'yi her zaman dinler.

Minguinho, Zezé Portekizli ile yakın arkadaş olup bütün vaktini onunla geçirmeye başlayınca kendisini ihmal ettiği zaman onu biraz kıskanır:

"Sen artık sadece Portekizliyle oynuyorsun ve ben bu oyuna katılamam." (Vasconcelos, 2018, s. 117)

Minguinho'nun yani şeker portakalının kitaptaki karakterler üzerinde çok bir etkisi yoktur. Her ne kadar ana karakter olsa da sadece Zezé'nin arkadaşı olarak varlığını sürdürür. Onu yönlendirici bir etkisi yoktur. Özellikle Zezé'nin Portekizliyle arkadaşığı sonrası ikinci planda kalmıştır. Portekizlinin ölümünden sonra Zezé girdiği şoktan çıkınca artık şeker portakalının büyüsünü kaybettiğini düşünür ve taşınacak olmalarııın da etkisiyle onunla bağlarını koparır. Buradan da anlaşılacağı gibi Minguinho yani şeker portakalı karakteri kapalı ve durağan bir karakterdir. Kapalı bir karakter olduğu için de okuyucunun ilgisini çekebilecek nitelikte olduğu söylenemez.

\section{Glória}

Kitaptaki yan karakterlerden biri olan Glória, Zezé'nin ablasıdır. Ailenin diğer bireylerinin aksine Zezé'ye merhamet gösteren tek kişidir. Zezé'yi her zaman korur ve onu çok sever. Aynı şekilde Zezé de Glória'yı çok sevmektedir. Kitapta anlatılanlardan yola çııılarak Glória'nın sadece merhametli bir karaktere sahip olduğu sonucuna ulaşılmaktadır. Öyle ki Zezé ayağını kesip eve geldiğinde kendince 
yarasını sardıktan sonra ev halkına Zezé'nin çok küçük olduğunu ve onu çok fazla dövdüklerini söyleyerek hep küçük kardeşini savunur. Bu da merhametli biri olduğunun göstergesidir:

"Bence onu çok fazla dövüyorsunuz. Bugün haşatını çıkarmışsınız. Bir günde üç kere de dayak atılmaz ki." (Vasconcelos, 2018, s. 111)

Glória karakteri kapalı ve durağan bir karakterdir. Tüm kitap boyunca Glória'nın karakter özelliklerine pek değinilmemiş, sadece kardeşi Zezé'ye karşı olan merhametinden bahsedilmiştir. Zezé ile olan ilişkisinden başka bir durumdan bahsedilmemiştir. Bu nedenle de kapalı karakter özelliği göstermektedir ve bu da okuyucunun ilgisini çekmeyebilir.

Tablo 5.

Şeker Portakalı: Karakterlerin Genel Görünümü

\begin{tabular}{llll}
\hline Karakterler & & Karakter Türü & $\begin{array}{l}\text { Karakterlerin } \\
\text { Geliştirilme Biçimi }\end{array}$ \\
\hline Zezé & Baş Kişi & Açı, Devingen & Dramatik \\
Manuel Valadares & Baş Kişi & Açı, Durağan & Dramatik \\
Şeker Portakalı & Baş Kişi & Kapalı, Durağan & Dramatik, Açıklama \\
Glória & Yan Kişi & Kapalı, Durağan & Dramatik, Açıklama \\
\hline
\end{tabular}

Yukarıdaki tabloya göre Şeker Portakalı adlı romanda incelenen karakterlerden Zezé devingen, diğerleri durağan özellik göstermektedir. Ayrıca bütün karakterlerin dramatik yöntemle oluşturulması, karakterlerin sahip oldukları özelliklerin gerçeğe uygun ve inandırıcı olmasını sağlamaktadır. Şeker Portakalı ve Glória karakterleri geliştirilirken dramatik yöntemle beraber açıklama yönteminin de kullanılması bu karakterler hakkında okuyucunun kafasında soru işaretleri oluşmasını önlemiştir.

Tablo 6.

Şeker Portakalı: Karakter Nitelikleri

Zezé Karakteri

Karakter Eğitiminde Kullanılabilecek Nitelikler Karakter Eğitiminde Kullanılamayacak Nitelikler

Hayalperest, Zeki, Meraklı, Duygusal Sinirli, Yaramaz

Zezé karakterinin karakter eğitiminde kullanılabilecek olumlu özellikleri olduğu gibi, karakter eğitiminde kullanılamayacak olumsuz özellikleri de bulunmaktadır. Karakterin sadece olumlu özelliklerden oluşmaması idealize edilmeyen, çocuk dünyasına daha yakın bir karakter olduğunu gösterir.

Tablo 7.

Şeker Portakalı: Karakter Nitelikleri

Manuel Valadares Karakteri

Karakter Eğitiminde Kullanılabilecek Nitelikler Karakter Eğitiminde Kullanılamayacak Nitelikler

Şefkatli, Kibar X

Manuel Valadares karakteri sadece olumlu karakter özelliklerine sahiptir. Bu özellikler de karakter eğitiminde kullanılabilecek özelliklerdir. Karakterin sadece olumlu özelliklerden oluşması idealize edilerek oluşturulduğunu göstermektedir. 
Tablo 8.

Şeker Portakalı: Karakter Nitelikleri

Şeker Portakalı Karakteri

\begin{tabular}{ll}
\hline $\begin{array}{l}\text { Karakter Eğitiminde } \\
\text { Kullanılabilecek Nitelikler }\end{array}$ & $\begin{array}{l}\text { Karakter Eğitiminde } \\
\text { Kullanılamayacak Nitelikler }\end{array}$ \\
\hline $\mathrm{X}$ & Kıskanç
\end{tabular}

Şeker Portakalı karakteri kapalı ve durağan bir karakter olduğu için karakter eğitiminde kullanılabilecek bir yapısı yoktur. Kitapta sadece Zezé'yi kıskandığı zaman bir devingenlik göstermiştir. Onun dışında hep pasif bir rolü vardır. Zezé’yle olan ilişkilerinde sadece Zezé izin verdiği kadar vardır. Bu nedenle idealize edilip edilmediğine dair yorum yapılamaz.

Tablo 9.

Şeker Portakalı ve Son Ada'nın Çocukları Romanlarının Karşılaştırılması

\begin{tabular}{lllll} 
& ŞEKER PORTAKALI & \multicolumn{2}{l}{ SON ADA'NIN ÇOCUKLARI } \\
\hline & Baş Kişi & Baş Kişi & Baş Kişi & Baş Kişi \\
\hline Açık Karakter & 2 & - & 2 & 1 \\
Kapalı Karakter & 1 & 1 & - & - \\
$\begin{array}{l}\text { Devingen } \\
\text { Karakter }\end{array}$ & 1 & - & - & - \\
Durağan Karakter & 2 & 1 & 1 & 1 \\
\hline
\end{tabular}

Yukarıdaki tabloda da görüldüğü gibi hem çeviri çocuk romanı olan Şeker Portakalı'nda hem de yerli çocuk romanı olan Son Ada'nın Çocukları'nda karakter nitelikleri olarak benzer bir şekilde verilmiştir. İki romanda da açık ve durağan karakter özellikleri yoğun olarak kullanılmıştır. Romanlardaki kişilerin açık karakter özelliği göstermesi okuyucunun karakterlerle özdeşim kurabilmesi açısından olumlu bir durum sayılsa da fazla sayıda açık karakter olması okuyucunun ilgisinin dağılmasına neden olabilir. Yine kitaplarda durağan karakter sayısının fazla olması da kitapların inandırıcılığını olumsuz yönde etkileyeceği için negatif bir durum olarak gösterilebilir.

\section{Tartışma ve Sonuç}

Çalışmadaki bulgulardan yola çıkılarak en çok baskı yapan yerli ve çeviri çocuk romanlarında karakter geliştirme yolları, karakter çeşitleri, karakterlerin özellikleri ve karakter eğitiminde kullanılıp kullanılamayacağı ile ilgili bazı sonuçlara ulaşılmıştır:

- Incelenen kitaplardaki toplam 5 baş kişiden 4'ü açık karakter, 1 'i kapalı karakter; 2 yan kişiden 1'i açık karakter, 1'i ise kapalı karakter özelliği göstermektedir. Baş kişilerden açık karakter özelliği gösteren 2 karakter çeviri çocuk romanında, 2 karakter ise yerli çocuk romanında yer almaktadır. Yan kişilerden açık karakter özelliği gösteren 1 karakter ise yerli çocuk romanında yer almaktadır. Baş kişilerin çoğunun açık karakter özelliği göstermesi okuyucunun kendisini karakterle daha kolay özdeşleştirmesini sağlamaktadır.

- Incelenen kitaplardaki toplam 5 baş kişiden 4'ü durağan karakter, $1^{\prime} i$ ise devingen karakter özelliği göstermektedir. Durağan karaktere sahip olan baş kişilerin çoğu olumlu özelliklere sahiptir. Bu durum herhangi bir sorun oluşturmamaktadır. Ancak olumsuz özelliklere sahip olan baş kişilerin durağan yapıda olması sorun olmaktadır. Çünkü karakter eğitiminde kullanılabilecek özellikler barındırmaması çocuk okurun kişilik gelişiminde olumsuz etki yaratabilir.

- Kitaplardaki toplam 2 yan kişiden 2'si de durağan bir yapıya sahiptir. Kitaplardaki kişilerin genellikle durağan yapıda olmasının karakter gelişimi açısından bakıldığında yerinde bir tercih olduğu söylenemez. 
- Incelenen kitaplardaki karakterler dramatik yöntemin yanı sıra açıklama yöntemi de kullanılarak oluşturulmuştur. Böylece karakterlerin tanıtılmasında okuyucunun aklında soru işaretlerinin kalmasının önüne geçildiği söylenebilir.

- Araştırma kapsamında incelenen Şeker Portakalı adlı romanda 3 baş kişiden 1'i; Son Ada'nın Çocukları romanındaki 2 baş kişiden ise 1'i idealize edilerek oluşturulmuştur. İdeallik kavramını oluşturan özelliklere sıkça yer verilerek bu kavram pekiştirilmiştir. Bunların yanı sıra olumsuz özellikleriyle ön plana çıkan karakterlere de yer verilmiştir.

- Kitaplardaki baş kişilerin çoğu idealize edilmeden oluşturulduğu için çocuk dünyasına yakın bir yapıda oldukları söylenebilir. Çünkü idealize edilmeden, günlük hayatta karşılaşma olasılı̆̆ı yüksek olan kahramanlar kitapların inandırıııı̆ı̆ı artırabilir ve çocukların ilgisini çekip onların kitaplarda kendilerini bulmalarını sağlayabilir. Böylece çocukların kitaplara olan ilgisi artabilir.

- Şeker Portakalı adlı romanda karakterler gerçekçi bir yapıda oluşturulmuştur. Yani karakterler günlük hayatta karşılaşılabilecek tiplerdir. Ancak Son Ada'nın Çocukları romanındaki karakterler ise idealize edilerek oluşturulmuştur. Günlük hayatta rastlanması pek mümkün olmayan tipler bulunmaktadır. Bu da kitabın inandırıcılığına gölge düşürebilir.

- Kitaplar genellikle ahlaki açıdan çatışma yaratacak şekilde oluşturulmuştur. Şeker Portakalı adlı romanda kitabın baş kişisi olan Zezé'nin ailevi sıkıntılardan da kaynakıı birtakım aykırı söz ve davranışları bulunmaktadır. Ancak kitapta karşılıksız sevgi ve merhametle bu tip durumların düzeltilebileceği mesajının sezdirilerek verilmesi ve Son Ada'nın Çocukları romanındaki Başkan karakterinin torununun adaya geldiğinde kötü kalpli, art niyetli bir görüntü oluşturmasına rağmen zamanla çevresindekilerin merhametli yaklaşımlarına duyarsız kalmaması ve olumlu yönde değişim göstermesi çocuk okurun karakter eğitimine olumlu katkı sağlayabilir.

- Araştırmada incelenen romanlarda karakter eğitiminde kullanılabilecek özellikler Şeker Portakalı romanında genellikle sezdirilerek, okuyucunun bilişsel yeteneğine bırakılarak verilmiştir. Son Ada'nın Çocukları romanında ise genellikle doğrudan verilmiştir. Bu da okuyucunun düşünmesine, muhakeme yeteneğini kullanıp geliştirmesine engel olabilir.

Sonuç olarak yerli çocuk romanlarından ve çeviri çocuk romanlarından seçilen bu iki kitap incelendiğinde farklı kültürlere ait kitaplar olmasına rağmen karakterlerin oluşturulma biçimleri ve davranış özellikleri paralellik göstermektedir. Kişilerin genel olarak çeşitli yollarla, çocukların duygu ve düşünce dünyasına yakın olarak oluşturulduğu görülmektedir. İncelenen kitaplarda genellikle başkişiler açık karakter, yan kişiler ise kapalı karakter özelliği göstermektedir. Bu kişiler ağırlıklı olarak durağan yapıda oluşturulmuştur. Son Ada'nın Çocukları romanında kişilerin karakter özellikleri genellikle abartıı ve çocuk gerçekliğine uzak olarak verilmiştir. Bu da romanların inandırıcılığını ve çocukların okuma isteğini azaltabilir. Şeker Portakalı romanında ise tersi bir durum söz konusudur. Karakterler günlük hayatta rastlanabilecek, olumlu ve olumsuz özellikleri beraber taşıyan bir yapıya sahiptir. Bu da romanın inandırıcılığına olumlu etki yapabilir. Ancak karakter eğitimi açısından bakıldığında kişilerin idealize edilmiş özellikleri özdeşim kurulmasının istenebileceği yapıda oluşturulmuştur. Özellikle hayvanseverlik, meraklılık, akıllı ve şefkatli olma, alçakgönüllülük, kibarlık gibi özellikleri çocuk okura aktarırken bu kitaplardaki karakterlerden yararlanabileceği sonucuna ulaşılımıştır.

Konuyla ilgili yapılan benzer çalışmalarda da bazı önemli sonuçlar elde edilmiştir. Karagül ve Ince Samur (2017) çalışmalarında ortaokul ders kitaplarında yer alan öykülerdeki kişileri karakter özellikleri açısından incelemiş ve bu öykülerdeki kişilerin genellikle metinler boyunca değişiklik göstermeden durağan bir yapı seyrettikleri sonucuna ulaşmışır. Bu da yapılan bu çalışmanın sonucuyla örtüşmektedir.

Çiçek ve Aksoy (2016), çalışmalarında inceledikleri çocuk romanlarında bulunan kişilerin günlük hayatın içinden ve çocukların özdeşim kurabilecekleri şekilde, açık ve devingen yapıda oldukları sonucuna ulaşmışlardır. Ancak ulaşılan sonuçlar bu çalışmanın sonucuyla örtüşmemektedir. Sarıkaya (2018) da benzer bir çalışmasında incelediği kitaplardaki kişilerin karakter özelliklerinin bu çalışmada incelenen kitaplardaki kişilerin karakter özellikleriyle örtüştüğü benzer sonuçlara ulaşmıştır. Çinpolat (2018) ise benzer bir çalışmasında Türkçe ders kitaplarındaki öykülerde incelediği karakterlerin çoğunun kapalı ve durağan özelliklere sahip olduğunu belirlemiştir. Bu sonuç da karakterlerin çoğunun 
durağan özellik göstermesi açısından bu çalışmanın sonuçlarıyla örtüşmektedir. Ancak yapılan bu çalışmada açık karakterler daha fazladır.

Tekşan, Set ve Çinpolat'ın (2019) çalışmalarında ele aldıkları kitaplarda incelenen karakterlerin açık ve durağan karakter özelliklerine sahip oldukları tespit edilmiş ve bu karakterlerin idealize edilerek oluşturulduğu belirlenmiştir. İncelenen karakterlerin olması gerekeni değil olması isteneni yansıttığı sonucuna ulaşıımıştır. Bu durum da yapılan bu çalışmanın sonuçlarıyla örtüşmekte ve çalışmanın sonuçlarını desteklemektedir.

Kurudayıoğlu, Baş ve Aytan (2013) tarafından yapılan çalışmada, 7. sınıf Türkçe ders kitaplarındaki hikâyeler karakter eğitimi açısından incelenmiştir. Çalışmada karakter eğitiminde kullanılabilecek sevgi, aile, cesaret gibi özellikler yoğun kullanılmıştır. Hikâyelerdeki karakterlerin niteliklerine bakıldığında ise açık karakter özelliğine sahip karakterlerin daha fazla olduğu tespit edilmiştir. İncelenen metinlerin iletilerinde karakter gelişimine etkili olabilecek özellikler (araştırma, bakış açısı, çalışkanlık, değer bilme, doğa bilinci, doğa sevgisi, irade, mücadele etme, planlı olma, takdir edilme) kullanılmıştır. Ulaşılan sonuçlar bu çalışmanın sonuçlarını desteklemektedir.

Işık (2017), karakter eğitimi açısından Mevlâna İdris Zengin'in hikâye ve masallarındaki eğitsel iletileri incelediği yüksek lisans tez çalışmasında açık ve durağan karakterlerin fazla olduğunu tespit etmiştir. Araştırma kapsamında incelenen eserlerdeki karakterlerin çoğunun olumlu özelliklere sahip olduğu görülmüştür. İncelenen eserlerde işlenen konuların ve verilmek istenen iletilerin çocuğa görelik ilkesine uygun olduğu sonucuna ulaşılmıştır. Yapılan bu çalışmayla karşılaştırıldığında benzer sonuçlara ulaşıldığı görülmektedir.

\section{Öneriler}

- Çocuk edebiyatı yazarlarının karakterleri oluştururken bu karakterleri devingen yapıda oluşturması önerilmektedir. Böylece kitapların daha ilgi çekici, hareketli ve okurun zihinsel yeteneklerini sorgulayan bir yapıda olmasına etki edebilir.

- Yazarlar kitaplarında, karakter eğitiminde çatışma oluşturabilecek durumlara daha çok yer vererek çocuk okurun sorgulama yeteneğini daha fazla kullanmasına katkı sağlayabilir. Çatışma yaratan durumların nasıl çözüleceği okuyucuya doğrudan değil de sezdirilerek verilirse çocukların kendi sorgulama yeteneklerini, bilişsel yeteneklerini daha aktif kullanmalarını sağlanabilir.

- Çocuk edebiyatı yazarları kitaplarını oluştururken çocuğa görelik ilkesini göz ardı etmemelidir. Karakterler gerçekçi bir şekilde ve abartılmadan oluşturulmalıdır. Böylece çocuklar okudukları kitaplarda kendi hayal dünyalarından bir şeyler bulabilir ve kitaptan daha çok zevk alabilir.

- Çocuk kitaplarında her sosyoekonomik düzeyden karakterlere ve kültürel çeşitliliğe yer verilmelidir. Bu sayede okuyucuların bakış açısı genişleyebilir ve kitabı daha keyifli bir şekilde okuyabilirler.

- Çocuklara kazandırılmak istenen ideal karakter özellikleri için onların okuyacakları kitaplar dikkatlice incelenmesi ve karakter eğitimine uygun olarak seçilmesi amaca daha doğru bir şekilde ulaşılmasını sağlayabilir.

- Çocuklar kitaplarla ilk olarak ailede tanıştıkları için ebeveynler çocukları yaş düzeylerine ve ilgilerine uygun, sevebilecekleri, karakter eğitimlerine olumlu yönde katkı sağlayacak kitaplarla buluşturmalıdır. Böylece hedeflenen kazanımlara daha rahat ulaşılabilir.

- Aile üyeleri çocuklar için kitap seçerken alanında uzman kişilerden yardım almalı ve araştırma yaparak kitap almalıdır. Bu sayede çocukların kitaplarla olan ilişkisi daha sağlıklı ve olumlu şekilde gelişebilir.

- Okul ve sınıf kütüphanelerinde nitelikli kitaplar bulundurulmalı, öğretmenler bu konuda titiz davranmalıdır. Çocukların gelişim özelliklerine göre kitaplar tercih edilmelidir.

- Çocuk kitabı yazarları eserlerini oluştururken çocuk edebiyatının temel ilkelerini göz ardı etmemelidir. 


\section{Araştırma ve Yayın Etiği}

Bu çalışmada "Yükseköğretim Kurumları Bilimsel Araştırma ve Yayın Etiği Yönergesi" kapsamında uyulması belirtilen tüm kurallara uyulmuştur. Yönergenin ikinci bölümü olan "Bilimsel Araştırma ve Yayın Etiğine Aykırı Eylemler" başlığı altında belirtilen eylemlerden hiçbiri gerçekleştirilmemiştir.

\section{Etik Kurul izni}

Çalışmada kitaplar incelendiği için etik kurul iznine ihtiyaç duyulmamaktadır.

\section{Yazarların Katkı Oranı}

1. yazar $\% 50$, 2. yazar $\% 50$ oranında katkı sağlamıştır.

\section{Çıkar Çatışması}

Çıkar çatışması teşkil edebilecek durumlar ve ilişkiler yoktur.

\section{Kaynaklar}

Akın, E. (2019). Çocuklar için edebiyat eğitimi. Ankara: Anı Yayıncılık.

Aslan, M. (2011). Illköğretimde karakter eğitimi ve öğrencilere kazandırılması gereken değerler (Yayımlanmamış yüksek lisans tezi). Eskişehir Osmangazi Üniversitesi, Eskişehir.

Baş, B. ve Ucuzsatar, N. (2020). Okul öncesi çocuk kitaplarındaki hayvan karakterlerinin geliştirilme yolları açısından incelenmesi. Uluslararası Türkçe Edebiyat Kültür Eğitim Dergisi, 9(1).

Çağatay, Ş. M. (2009). Öğretmen görüşlerine göre karakter eğitiminde ve karakter gelişiminde okulun rolü (Yayımlanmamış yüksek lisans tezi). Çanakkale On Sekiz Mart Üniversitesi, Çanakkale.

Çiçek, M. ve Aksoy, S. (2016). İsmet Bertan, Sevim Ak ve Görkem Yeltan'ın çocuk romanlarındaki başkahramanların çözümlenmesi. Sosyal Bilimler Dergisi, 3(7), 113-131.

Çinpolat, E. (2018). Türkçe ders kitaplarında yer alan öykülerdeki kişilerin karakter özellikleri üzerine bir inceleme. Ana Dili Eğitimi Dergisi, 6(4), 1016-1040.

Davis, M. (2003). What's wrong with character education?. American Journal of Education, 110(1), 3257.

Dönmez, S. ve Koçak, Ş. (2018). Kutadgu Bilig'de çocuk eğitimi. Akra Kültür Sanat ve Edebiyat Dergisi, 15, 145-192.

Gönen, M. (2019). Erken çocukluk döneminde çocuk edebiyatı. Ankara: Eğiten Kitap.

Işık, M. (2017). Karakter eğitimi açısından Mevlâna idris Zengin'in hikâye ve masallarında eğitsel iletiler (Yayımlanmamış yüksek lisans tezi). Recep Tayyip Erdoğan Üniversitesi, Rize.

Karagül, S. ve İnce Samur, A. Ö. (2017). Ortaokul Türkçe ders kitaplarında yer alan öykülerdeki karakter özelliklerinin incelenmesi. Ana Dili Eğitimi Dergisi, 5(2), 336-352.

Karasar, N. (2012). Bilimsel araştırma yöntemi. Ankara: Nobel Yayın Dağıtım.

Karatay, H. (2011). Karakter eğitiminde edebi eserlerin kullanımı. TurkishStudies, 1(6), 1398-1412.

Karataş, E. (2014). Çocuk edebiyatında "Karakter" kavramı. Muğla Sıtkı Koçman Üniversitesi Sosyal Bilimler Enstitüsü Dergisi, 33.

Kurudayıoğlu, M., Baş, B. ve Aytan, N. (2013). 7. sınıf Türkçe ders kitaplarındaki hikâyelerin karakter eğitimi açısından incelenmesi. Ana Dili Eğitimi Dergisi, 1(4), 22-37.

Lickona, T. (1993). There turn of character education. Educational Leadership, 51(3), 6-11.

Lukens, R. J. (1999). A critical handbook of children's literature. New York: Longman.

Merriam, S. (2013). Qualitative research a guide to design and implementation. Ankara: Nobel Yay.

Milson, A. ve Ekşi, H. (2003). Öğretmenlerin karakter eğitiminde yetkinlik duygusu konusunda bir ölçme aracına doğru: Karakter Eğitimi Yetkinlik İnancı Skalası (KEYiS) ve Türkçeye uyarlanma çalışması. Değerler Eğitimi Dergisi, 1(4), 99-130.

Moddings, N. (2006). Eğitim ve mutluluk. İstanbul: Kitap Yayınevi.

Özdemir, E. (1995). Eleştirel okuma. Ankara: Ümit Yay.

Sarıkaya, H. (2018). Muzaffer izgü'nün çocuk romanlarındaki karakterlerin incelenmesi (Yayımlanmamış yüksek lisans tezi). Gaziantep Üniversitesi, Gaziantep. 
Sarıüce, H. L. (2012). Türk çocuk ve gençlik edebiyatı ansiklopedisi. İstanbul: Nar Yay.

Sever, S. (2008). Çocuk ve edebiyat. İmir: Tudem.

Sınar Çılgın, A. (2007). Çocuk edebiyatı. İstanbul: Morpa Kültür Yay.

Şimşek, T. (2018). Kuramdan uygulamaya çocuk edebiyatı. Ankara: Grafiker Yay.

Tekin, M. (2004). Roman sanatı. İstanbul: Ötüken Yay.

Tekşan, K., Set, G., \& Çinpolat, E. (2019). Çocuk kitapları ve idealist kahramanlar. Mehmet Akif Ersoy

Üniversitesi Eğitim Fakültesi Dergisi, 51, 241-261.

TDK (2011). Türkçe sözlük. Ankara: Türk Dil Kurumu Yay.

Uç, H. (2006). Roman eleştiri terimleri. Ankara: Bizim Büro Basımevi.

Wynne, Edward (1985). The great tradition in education: Transmitting moral values. Educational Leadership, 43(4), 4-9.

Yılmaz, O. (2016). Kurgusal nitelikli çocuk kitapları ve karakter eğitimi. Ana Dili Eğitimi Dergisi, 4(3), 311-325.

http://www.cortland.edu/character/ce_iv.html/ (Erişim Tarihi: 22.06.2020)

\section{Introduction}

\section{Extended Abstract}

Children's literature is the type of literature created in accordance with the feelings and thoughts of the child, further taking cognitive development level of the child into account (Şimşek 2018, p. 40). According to Sever (2008, p. 17), children's literature is the form of literature that enriches the worlds of emotions and thoughts with works that possess an aesthetic value, in accordance with the cognitive development levels of children, including the early childhood and adolescence period. Since children form the basis of children's literature, it is expected that the works conform to their levels of understanding, comprehension, and interest in terms of language, subject, and expression (Sarıyüce 2012, p. 9).

Besides the cognitive, mental and emotional effects of children's literature on children, there is also the noteworthy benefit towards the lingual development of the children. Since books, which form a large part of the children's literature, are written in accordance with the language level of the children, they are created in a way that reflects their level. In addition, since children imitate the characters they read in books, the desired effects of children's books can be far more easily and efficiently reached by taking note of these points (Akın 2019, p. 106-107). Alongside the positive effects of children's literature products, negative effects can also be observed. Afterall, children create their imaginary worlds, further their analysis skills and add to their level of knowledge through the output of these literary products. Children may also strive to imitate and re-enact the protagonists of the books they read. As such books with negative expressions, characters, examples may negatively affect a child's character development.

In order for children to identify themselves with the characters in the books, these characters must be realistic enough to be encountered in everyday life and at the child reader's age level in order to strengthen the characters' credibility and reliability (Şimşek 2018, p. 101). In this way, children will be eager to behave and think in line with the characters they read whose will to live, problem solving skills and determination to achieve their goals are tempered with realistic behaviours and expressions (Sever 2008, p. 77).

Heroes give life to many characters with their personality traits. The main thing that brings them to the fore and allows children to identify with themselves is the characters of the heroes. Therefore, there are certain characteristics that the characters must possess. According to Karatay (2011, p. 100), characters should have universal and moral principles, always fight for righteousness and truth, be on the side of peace, defend the environment and cultural values, and have positive personality features.

Sever (2008, p. 104-105) has classified these characters according to their types as open, closed, static and dynamic characters.

There has been a number of research conducted regarding the types of character developments in literary works and what must be considered at these stages. According to Lukens 
(1999), characters can be developed by their "behaviors and actions, forms of speech, physical attributes (superficial traits), opinions of other characters and through the intervention of the author" (Lukens, 1999).

According to Özdemir (1995, p. 110), some of the ways of creating the characters are direct in nature, such as displaying their physical appearance and dress, as well as showing their inner life. Some of these development methods function indirectly. That is, it is done by reflecting on their behaviours and expressions. In summary, this means characters are formed through statements or depictions. However, they must be used in conjunction with one another, as no single method is sufficient on its own.

A method of character development is the "explanatory method", wherein information about the character to be introduced is disclosed by the author directly. Another method is the "dramatic method", wherein the traits and attributes of the character are expressed through their behaviours, emotions and thoughts. These methods can be used in complementation or on their own. In the "dramatic method", information about the characters is not given at once but instead revealed throughout the books in instances where the characters' emotional and cognitive systems, their lives and their interactions with their surroundings are represented. In the "explanatory method", all the information about the characters is defined by the author and the experiences of the characters are not taken into account as a factor in their development. On the other hand, it should be noted that readers may immediately put together all the information about a character developed through the "dramatic method" and identify them. In such circumstances, the "explanatory method" may be utilized (Tekin 2004, p. 80-81). As it will become clear on the basis of information provided, the use of the "explanatory method" in conjunction with the "dramatic method" may be more beneficial to the reader's ability to comprehend and sense the characters in full.

\section{Method}

The study was conducted utilizing a qualitative research design known as the basic qualitative research design. The basic qualitative research design is one of the most widely used qualitative research patterns, with applications in a wide range of subjects and fields. Data is gathered through interviews, observations, or document analysis in this type of research (Merriam 2013). With this research model, the literature was scanned and the qualities of the characters, how they were developed, their features and their use in character education were tried to be determined.

The scope of the study consists of most printed translated children's novels and local children's novels. The case material is composed of two most widely printed children's novels: a local one and a translated one. These were determined by the sampling method for sampling purposes.

The novels used in the study are;

- Son Ada'nın Çocukları

- Şeker Portakalı

In this given analysis process, the selected local and translated books were read with emphasis on their usage of the concept of person. With the content analysis method, the people in these books were analyzed according to the criteria that constitute the character qualities and development styles in accordance with the purpose. During the processing phase, the characters in the books selected for the purpose were evaluated and judged on the basis of the following; Sever's (2008) Çocuk ve Edebiyat book on the basis of the criteria of openness and closeness, stasis or dynamism; Tekin's (2004) development methods and suitability for character education described in his book Roman Sanatı.

\section{Result and Discussion}

As a result, despite being books from different cultures, the way the characters are developed and their behavior features exhibit parallelism when these two books, which were selected from local children's novels and translated children's novels, are evaluated. It is observed that characters are created in a variety of means in conceptual closeness to the worlds of emotion and thought of children. Leading characters in the analyzed texts are frequently open characters, whereas supporting/background characters are frequently closed ones. Characters like these are frequently 
developed in a static structure. Character features are often exaggerated and presented in a manner that is distant from a child's reality in the novel Son Ada'nın Çocukları. This can reduce the credibility of the novels and the desire of children to read. An opposite circumstance exists in the novel şeker Portakalı. Characters in the book carry both positive and negative traits, thereby more closely resembling reality. This may result in a more elevated level of immersion in the book. However, when viewed from a character development perspective, the idealized traits of the characters are in line with their potential to reach identification by the reader. It has been concluded that the characters in these books can be benefited from while conveying traits such as love of animals, curiosity, intelligence and empathy, humility and pride to child readers. 